\title{
Wykorzystanie tachimetrii i fotogrametrii w dokumentacji zabytków architektury na przykładzie inwentaryzacji pomiarowo-rysunkowej wybranych kamienic toruńskich
}

\section{Wstęp}

edna z podstawowych form dokumentacji zabytków jest inwentaryzacja
pomiarowo-rysunkowa. Widoki i plany najważniejszych budynków były
już sporządzane w XVI-wiecznym Rzymie ${ }^{1}$. Przez kolejne stulecia doskonalono techniki pomiaru². Obecnie istnieje szereg wytycznych do sporządzania tego rodzaju dokumentacji ${ }^{3}$. Do jej wykonania stosuje się trzy zasadnicze metody: pomiar ręczny z użyciem dalmierzy laserowych; pomiar laserowy w wykorzystaniem tachimetrii, fotogrametrię oraz coraz popularniejszy ostatnio skaning laserowy ${ }^{4}$. Zwłaszcza ten ostatni daje graficznie

1 M. Arszyński, Idea, pamiéć, troska. Rola zabytków w przestrzeni spotecznej i formy dziatania na rzecz, ich ochrony, Malbork 2007, s. 49 i in.

2 M. Brykowska, Metody pomiarón i badań zabytków architektury, Warszawa 2003, s. 9-48.

3 G. Eckstein, J. Gromer, Empfehlungen für Bauaufnahmen, Stuttgart 1990; G. Eckstein, Empfehlungen für Baudokumentationen, Stuttgart 1999. Inwentaryzacje pomiarowo-rysunkowe prowadzone w Zakładzie Konserwatorstwa oparte są na wewnętrznej instrukcji. Zob. H. Ratajczak, W. Kania, „Konserwatorska dokumentacja pomiarowo-rysunkowa obiektu zabytkowego", Toruń 2012, mps w zbiorach Zakładu Konserwatorstwa.

4 W kilku ośrodkach akademickich prowadzone sa na ten temat zaawansowane badania. Zob. A. Boroń, M. Borowiec, A. Wróbel, Rozwój cyfrowej technologii inwentaryzacji obiektón 
bardzo spektakularne wyniki. Z uzyskanej chmury punktów można bowiem uzyskać fotoplany lub nawet animacje. Powstaje jednak pytanie, na ile taka dokumentacja jest przydatna $\mathrm{w}$ badaniach oraz samym procesie konserwacji i restauracji zabytków architektury.

W 2014 r. Wydział Sztuk Pięknych Uniwersytetu Mikołaja Kopernika w Toruniu rozpoczął realizację projektu pt. „Wielomodułowe interdyscyplinarne badania nieniszczące obiektów architektury na przykładzie gotyckich kamienic mieszczańskich w Toruniu"5. Jednym z jego podstawowych założeń jest próba przebadania zespołu zabytkowych budynków za pomoca geodezyjnych metod pomiarowych w połączeniu z wynikami działań georadaru i szeregu badań technicznych ${ }^{6}$.

Pierwszym zadaniem było wykonanie inwentaryzacji pomiarowo-rysunkowej ${ }^{7}$. Do tego celu wykorzystano tachimetr firmy SOKKIA wraz z opro-

zabytkowych na prayketadzie dośmiadczeń Zakładu Fotogrametrii i Informatyki Teledetekcyjnej AGH, Archiwum Fotogrametrii, Kartografii i Teledetekcji, vol. 19, 2009, s. 11-22. Wśród wielu tekstów poświęconych wykorzystaniu tachimetrii, fotoplanu oraz skaningu laserowego zob. np.: A. Boroń, A. Rzonca, A. Wróbel, Metody fotogrametrii cyfrowej i skanowania laserowego w inwentaryzacji zabytków, „Rocznik Geomatyki”, t. V, 2007, z. 8, s. 129-140; J. Kościuk, Wspótczesne skanowanie laserowe 3D w modelowaniu, dokumentacii i konserwacij zabytków architektury, „Wiadomości Konserwatorskie” 2012, nr 32, s. 82-89; A. Gołębnik, Rola nonych technik. dokumentacyjno-pomiarowych w interdyscyplinarnych dziataniach badawczo-konserwatorskich, „Wiadomości konserwatorskie" 2014, nr 40, s. 83-93; L. Kisiecki, P. Klak, Cyfrowa dokumentacja odkrytych reliktón $i$ badania geofizyczne w dawnym kościele ewangelickim Żłóbka Chrystusa (Kripplein Christi) we W schowie, „Lubuskie Materiały Konserwatorskie” 2014, t. 11, s. 83-90.

5 Projekt prowadzony jest w ramach Działania 5. Wzmocnienie regionalnego potencjału badań i rozwoju technologii, w ramach Osi priorytetowej 5.4 Wzmocnienie konkurencyjności przedsiębiorstw, Regionalnego Programu Operacyjnego Województwa Kujawsko-Pomorskiego na lata 2007-2013. Zob. strona projektu: http://www.projektmostowa6.umk.pl/, 19.02.2015. Projekt jest współfinansowany ze środków Europejskiego Funduszu Rozwoju Regionalnego w ramach Regionalnego Programu Operacyjnego Województwa Kujawsko-Pomorskiego na lata 2007-2013 oraz ze środków Budżetu Państwa.

${ }^{6}$ Wykorzystując metody fotogrametryczne wykonano częściowo m.in. dokumentację Kościoła Pokoju w Świdnicy. Zob. Dokumentacja pomiarowo-rysunkowa Kościoła Pokoju w Świdnicy, oprac. B. Zimnowoda-Krajewska, E. Okoń, M. Tużyniecka, Toruń 1992, mps w zbiorach Zakładu Konserwatorstwa UMK; E. Okoń, Uwagi o inwentaryzacji architektoniczno-konserwatorskiej wię́by dachowej Kościoła Pokoju po. Św. Trójcy w Świdnicy, [w:] Wzorcowe badania historyczne i restauratorskie i prace konserwatorskie w Kościele Pokoju pw. Św. Trójcy w Świdnicy, pod kier. M. Gernera i U. Schaafa, Świdnica 1994.

7 Zadanie to wykonywane było przez dr. Macieja Prarata oraz Magdalenę Kumorowicz i Martynę Grabowska. W miejscu tym chciałbym serdecznie podziękować koleżankom za ciężką i owocną pracę. 
gramowaniem TachyCad i PhotoPlan firmy KUBIT (il. 1) ${ }^{8}$. Wybór właśnie takiego sprzętu podyktowany był prowadzoną na Wydziale dydaktyką. $\mathrm{Na}$ kierunku Ochrona Dóbr Kultury, specjalność konserwatorstwo od 2010 r. prowadzone sa przedmioty: tachimetria i fotogrametria ${ }^{9}$, na których to wykorzystywany jest sprzęt i oprogramowanie zastosowane do prezentowanej tu dokumentacji.

Niniejszy tekst jest podsumowaniem pierwszej części projektu, spełniając jednocześnie funkcję skryptu dla studentów konserwatorstwa ${ }^{10}$. Jego głównym celem jest przedstawienie metody pracy oraz określenie jej przydatności i opłacalności w kompleksowych badaniach zabytków architektury i późniejszych prac konserwatorskich.

\section{Prezentacja kamienic}

Zabytkami wytypowanymi do przeprowadzenia kompleksowych badań był zespół trzech budynków znajdujących się na ulicy Mostowej, pod wspólnym numerem $6^{11}$. Kamienice te stanowia jeden $z$ bardziej charakterystycznych i jednocześnie zaniedbanych zabytków miasta (il. 2). Usytuowane są w południowo-zachodniej części Starego Miasta, w pierzei wschodniej ulicy, wchodzacej w skład bloku ograniczonego dodatkowo ulicami Ciasna i Podmurnac.

Wszystkie ustawione sa szczytami do ulicy Mostowej. Po stronie wschodniej kamienica północna i południowa połączona jest z oficynami. Łącznie ze spichlerzem od strony Podmurnej układ ten tworzy zamknięty dziedziniec z wjazdem.

8 http://www.kubit-polska.com/CAD/Products/index.php, 19.02.2015.

$9 \mathrm{Na}$ pierwszym roku drugiego stopnia odbywaja się przedmioty: Tachymetria $(30 \mathrm{~h})$ oraz Fotogrametria $(15$ h). Program studiów dostępny na stronie WSzP. Zob. http://www. art.umk.pl/kier_stud/pdf/programy_plany_stud/odk-s/program_ramowy_odk-ii_st_s.pdf, 19.02.2015.

10 Przy omawianiu metody pracy za pomoca tachimetra i fotogrametrii podawane będa w przypisach komendy, tak aby ułatwić studentom późniejszą pracę z oprogramowaniem.

${ }_{11} \mathrm{~W}$ miejscu tym autor chciałby serdecznie podziękować Pani Mirosławie Romaniszyn Miejskiemu Konserwatorowi Zabytków za pomoc przy wyborze i udostępnieniu budynku. 
Każda z kamienic zbudowana jest na rzucie wydłużonego prostokąta. Kamienica północna (dalej: C), pięciokondygnacyjna oraz środkowa (dalej: B), sześciokondygnacyjna mają układ dwutraktowy, południowa zaś (dalej: A), również sześciokondygnacyjna, jednotraktowy. Wejście główne do całego zespołu prowadzi przez kamienicę C (il. 4). W jej głównej sieni znajdują się kręcone schody prowadzące na wyższą kondygnację, wejście do nieczynnego sklepu, mieszkania po stronie południowej (w budynku B) oraz mieszkania w trakcie wschodnim. W ścianie południowej znajduje się przejście do korytarza w kamienicy B, który prowadzi na podwórze. W jego wschodnim trakcie (B) znajdują się schody prowadzące na wyższe kondygnacje. Ciag komunikacyjny wyznaczają kolejne schody jednobiegowe, prowadzące do mieszkań w kamienicy C, oraz magazynów i poddaszy wszystkich trzech budynków. Z drugiego piętra kamienicy B prowadzi wejście do kamienicy A. Do piwnicy kamienicy C i B prowadzą szyje piwniczne w elewacji zachodniej. Do piwnicy kamienicy A można się dostać jedynie $z$ sieni.

Elewacje zachodnia, jak i wschodnia mają ujednoliconą formę, choć w strukturze muru widoczne są liczne wcześniejsze przebudowy. Fasada zachodnia (każda z kamienic, powyżej parteru ma układ trójosiowy) zwieńczona jest trzema szczytami o formie półkolistej, z podwójnym układem sterczyn pomiędzy nimi. Elewacje wschodnie o zdecydowanie mniej rozbudowanej formie, zwieńczone są szczytami trójkątnymi.

Wszystkie budynki wykonano z cegły i kamienia polnego (w partii piwnicznej). Stropy wszystkich kondygnacji kamienic B i C sa drewniane, częściowo z podsufitkąa ${ }^{12}$. Kamienica $\mathrm{B}$ ma prostą więźbę jętkowa, zaś $\mathrm{C}$ storczykowa, zredukowaną. W przypadku kamienicy A, po jej spaleniu w 2008 r., założone nowe stropy w systemie WSP oraz drewniana, jętkową więźbę dachową $^{13}$. Z wyposażenia zachowane są drewniane schody kręcone z końca XVII w., oraz częściowo stolarki okienne i drzwiowe z XIX i XX w.

12 W przypadku kamienicy B w trakcie zachodnim znajduje się sklepienie kolebkowe, w trakcie wschodnim strop gęstobelkowy.

13 E. Okoń, „Sprawozdanie z nadzoru konserwatorskiego prowadzonego od dnia 4 X 2007 do dnia 15 II 2008 r. przy pracach zabezpieczających w budynku południowym kamienicy przy ul. Mostowej $6 \mathrm{w}$ Toruniu", mps w zbiorach E. Okonia. 
Dotychczasowy stan badań pozwala nam również na ogólne przedstawienie historii tych budynków ${ }^{14}$. Wiadomo, że obecne kamienice stoją na miejscu wcześniejszej zabudowy, prawdopodobnie z końca XIII/początku XIV w. Z początku XV w. pochodzi widoczna pod przemurowaniami schodkowa elewacja kamienicy A. Obecny wygląd zespół ten otrzymuje ok. połowy XVI w., kiedy to przebudowane zostaja szczyty C i B. W XVII w. dostawiony zostaje do nich obecny szczyt A. W kolejnych wiekach budynki te podlegały zmianom jak większość zabudowy miejskiej, tj. partery przerabiane były na sklepy, zaś funkcja domu jednorodzinnego ustapiła funkcji czynszowej ${ }^{15}$.

\section{Prezentacja}

\section{wykonanej inwentaryzacji pomiarowo-rysunkowej}

Przedstawiony zespół budynków uświadamia nam, z jak niezwykle skomplikowaną funkcjonalno-przestrzenną kubaturą mamy tu do czynienia. Jego wartość została dostrzeżona już dawno. Podstawową dokumentację pomiarowo-rysunkową w skali 1-50 wykonano w 1957 r. pod kierunkiem prof. Stefana Narębskiego ${ }^{16}$. Dodatkowo w 1983 r. opracowano inwentaryzację

14 Najważniejsza praca jaka powstała do tej pory są badania architektoniczne elewacji zachodniej, przeprowadzone przez Ireneusza Sławińskiego w 1971 r. oraz dokumentację historyczną wykonaną przez Jerzego Frycza. Zespół tych budynków był również omawiany w większości ogólnych prac poświęconych zabytkom Torunia. Zob. I. Sławiński, Badania architektoniczne elewacij frontowej budynku Mostowa 6, mps w zbiorach MKZ, Torun 1971, sygn. 4492; J. Frycz, „Spichrze przy ul. Mostowej 6 w Toruniu. Wstępna dokumentacja naukowa opracowana do użytku PP PKZ”, mps w zbiorach WUOZ, Toruń 1957, bez sygn.; E. Gąsiorowski, Toruńska kamienica miesžczańska, „Zeszyty Naukowe Uniwersytetu Mikołaja Kopernika w Toruniu. Zabytkoznawstwo i Konserwatorstwo", z. 1, Torun 1966, s. 69-109; idem, Późnogotyckie szcsyty o pótkolistych zwieńczeniach w kamienicach miast dawnych Prus Królewskich, [w:] Conservatio est aeterna creatio. Ksiega dedykowana prof. Janowi Tajchmanowi, Toruń 1999, s. 171-193; J. Tajchman, Toruńskie elewacje w typie trw. Domu Kopernika, „Stare i Nowe Dziedzictwo Torunia”, t. 1, Toruń 2013, s. 126-143.

15 I. Sławiński, op.cit., s. 23-37.

16 Dokumentacja ta składa się z 11 rysunków, w tym 5 rzutów, 1 przekroju poprzecznego, 2 elewacji (dla wszystkich budynków razem) oraz osobno 3 przekrój podłużnych. Zob. „Inwentaryzacja pomiarowo-rysunkowa budynku na ul. Mostowa 6”, oprac. zespół pod kierunkiem prof. S. Narębskiego, mps w zbiorach MKZ, Toruń 1957, bez sygn. 
fotogrametryczną przez Okręgowe Przedsiębiorstwo Geodezyjno-Kartograficzne w Bydgoszczy w skali 1-20 (il. 3) ${ }^{17}$.

Dokumentacje te stały się punktem odniesienia do opracowania nowej przy wykorzystaniu tachimetrii i fotoplanu. Podczas zbierania pomiaru rzuty, przekroje poprzeczne oraz elewacje wykonywane były dla całego zespołu łącznie (il. 4). Dopiero na etapie opracowania podzielono je osobno na każdą z kamienic. Dla wszystkich budynków wykonano łącznie 40 rysunków na formacie A1-A4, tj. rzuty piwnic, przyziemia oraz wszystkich kondygnacji z widokiem więźb i połaci dachowych, przekroje podłużne z cięciem pokazującym wszystkie biegi schodów - dla B (il. 5) lub widok całych schodów kręconych dla C. Dla kamiennicy A założono dwa przekroje podłużne z całościowym rozwinięciem ściany północnej (il. 6) i południowej. Nieco inaczej, w stosunku do starej dokumentacji, postapiono w przypadku przekroju poprzecznego. Założono bowiem wykonanie dwóch cięć. Jednego przez pierwszy trakt z widokiem na ścianę zachodnią oraz drugiego przez drugi trakt z widokiem na ścianę wschodnią (il. 7). Dla całości przyjęto skalę 1-50. Osobno wykonano rysunek kręconych schodów w skali 1-20 (il. 8). Widoki elewacji wykonano za pomoca fotogrametrii (il. 9). Mając na uwadze niekonsekwencje opracowania fasady z lat 80 . XX w., określono, że dokładność przerysu (biorąc pod uwagę również skalę dokumentacji) ograniczy się do pokazania warstw cegiel ${ }^{18}$. Fotogrametrię zastosowano również do rozrysowania szczytów widzianych od środka w przekrojach poprzecznych, czy rozwinięciach ścian, gdzie w pełni widoczne były warstwy cegieł. Tak zaprogramowane działania miały na celu opracowanie rysunków ukazujących obecny stan zachowania budynków, będąc jednocześnie jak najdokładniejszym podkładem pod badania architektoniczne i radarowe.

17 Rysunki przechowywane są w archiwum MKZ.

18 Elewacja wykonana w latach 80. XX w. jest niekonsekwentna. Nie ma uzasadnienia zróżnicowanie rysunku, gdzie raz rysowane są poszczególne cegły z widoczną zaprawą gdzie indziej zaś jedynie warstwy. Daje to fałszywy obraz mogący wprowadzić w błąd, zwłaszcza przy analizie badań architektonicznych. Uwagi te nie dotyczą samej dokładności pomiaru, które pokrywają się z prezentowaną tu dokumentacją. 


\section{Przyjęta metoda pomiaru}

Pomiar trzech kamienic miał miejsce w lipcu i sierpniu 2014. Zebranie materiału dla trzech kamienic zajęło ok. 6 tygodni pracy. Bezpośrednio przy urządzeniu pracowały trzy osoby. Jedna obsługiwała komputer z Aut ${ }^{\circ} \mathrm{Ca}-$ dem, druga tachimetr, trzecia zaś sprawdzała położenie wiązki laseru, przy dalszych odległościach. Przed przystapieniem do pracy w pliku Cad założono warstwy dla każdego z rysunków, przekrojów, widoków i wszystkich rzutów z osobna. Linie podzielone grubością, formą i kolorem na widokowe, przekroju drewna i muru oraz zrzutowanego widoku z góry. Podczas zbierania pomiaru laserem od razu rysowano na odpowiedniej warstwie, domierzając i uzupełniając na miejscu rysunek, tam gdzie nie było możliwości skierowania wiązki lasera.

Przed przystapieniem do mierzenia należało najpierw ustawić w programie Aut ${ }^{\circ} \mathrm{Cad}$ zmianę widoku rysunku przy zmianie $\mathrm{UCS}^{19}$, następnie już w zakładce TachyCad określić położenie instrumentu ${ }^{20}$. W dalszej kolejności założono układy współrzędnych (tzw. UCS) dla rzutu i wszystkich przekrojów, nadając im odpowiednie nazwy ${ }^{21}$. Niezmiernie istotne jest, aby w przypadku pomiaru różnych płaszczyzn z jednego ustawienia pracować na pełnej wersji oprogramowania Aut ${ }^{\circ} \mathrm{CAD}, \mathrm{z}$ możliwościa pracy w 3D. Wykorzystywany w początkowej fazie Aut ${ }^{\circ} \mathrm{Cad}$ LT choć działał, uniemożliwiał wprowadzanie ręcznego domiaru bezpośrednio w otworzonej płaszczyźnie ${ }^{22}$.

\footnotetext{
19 Zakładka Aut ${ }^{\circ} \mathrm{CAD}$ : Visualize - Coordinates - Settings - Update view to Plan when UCS is changed.

20 Zakładka: TachyCad - New/Edit orientation - Local orientation.

${ }^{21} \mathrm{~W}$ przypadku układów wertykalnych, oś X wyznaczamy za pomocą dwóch punków, w kierunku od lewej do prawej. Zakładka: TachyCad Building - Vertical view (USC) through 2 points. W przypadku rzutów, UCS musi być wyznaczony za pomocą 3 punktów - określenie pierwszego punktu na osi X- określenie drugiego punktu na osi X, określenie punktu na osi Y, określenie początku układu współrzędnych. Zakładka: TachyCAD Building - New UCS through 3 or more points.

22 Wynika to z automatycznego spłaszczania rysunków w wersji 3D. Pełne oprogramowanie dedykowane do pracy w płaszczyznach, ma również ułatwienia w postaci gotowych ikon zmiany USC, co przyspiesza pracę.
} 
Po ustawieniu instrumentu i założeniu UCS kolejną czynnością było wyznaczenie punktów kontrolnych, za pomocą których możliwe było przestawienie instrumentu $\mathrm{w}$ inne miejsce (tzw. wcięcie przestrzenne) ${ }^{23}$. Istotnym jest, aby punkty wyznaczyć w taki sposób, aby przynajmniej trzy z nich widoczne były po zmianie ustawienia ${ }^{24}$. Dla czytelności rysunków i samych punktów kontrolnych przyjęto jeden system ich oznaczenia. Najpierw określano kamienicę A, B lub C, dalej zaś kondygnację 0 - piwnica, 1 - parter, itd., na końcu zaś numer punktu na danej kondygnacji. I tak ósmy punkt na pierwszym piętrze kamienicy północnej był oznaczony jako C2.8. System ten znacznie usprawnił możliwość odnalezienia danego punktu. Trzeba tu zaznaczyć, że w przypadku wykonanych prawie 40 rysunków, dla trzech budynków o pięciu i sześciu kondygnacjach ich ilość była bardzo duża.

Przed przystapieniem do pracy na każdej kondygnacji założono kredą poziom porównawczy, aby mieć odniesienie do miejsca cięcia rzutu. Zabieg ten był niezmiernie istotny w przypadku budynku o takich odchyłach jak prezentowane kamienice. Po wykonaniu wszystkich tych czynności można było przystapić do pomiaru. Praca musiała być wykonywana bezpośrednio na dedykowanych warstwach, z domierzaniem ręcznie miejsc niedostępnych. Każdy wykonany przekrój i rzut rozpoczynano od narysowania linii przekroju. Dalej zaś sprawdzano, czy widoczne są linie widokowe narożników, które również zaznaczano, jeśli było to możliwe. Następnie obrysowywano widoki ścian. W przypadku otworów okiennych i drzwiowych zaznaczano jedynie ich światło. Stolarki były domierzane i wprowadzane ręcznie.

W przypadku zastosowania Photoplanu koniecznym było założenie punktów kontrolnych po obwodzie wykonywanego zdjęcia (min. 4 punkty $)^{25}$. Dla nich utworzono osobna warstwę, nadając do przyjętej numeracji budynku A, B lub C literkę P, np. APO.3 - trzeci punkt fotoplanu w piwnicy kamienicy południowej. W bardzo wielu momentach, np. na

\footnotetext{
23 Założenie punktów odbywa się za pomocą okularu tachimetra. Zakładka: TachyCAD - Measure nwe control point.

24 Zmiana ustawienia instrumentu zob. zakładka: TachyCAD - New/Edit orientation Free Station.

25 Procedura zakładania punktów była taka sama jak w przypadku standardowych punktów kontrolnych. Patrz przypis 20.
} 
znacznej wysokości, nie było możliwości założenia tarczy pomiarowej. Wtedy najpierw wykonywano zdjęcie ${ }^{26}$. W podstawowym programie graficznym oznaczano wybrany charakterystyczny punkt, który przyjmowano za pomiarowy, np. narożnik cegły. Następnie zbierano pomiar za pomocą tachimetru. Po zakończeniu zbioru danych na ścianie, prostowano zdjęcia ${ }^{27}$ i łączono je w jedna całość ${ }^{28}$. Oczywiście najlepiej jest aby zdjęcie było wykonane jak najbardziej pod katem prostym o średniej ogniskowej obiektywu. Nie zawsze było to jednak możliwe. Dla przykładu elewacja wszystkich kamienic wykonana została za pomocą dziewięciu zdjęć (po trzy na każdą elewację) robionych z ulicy. Aby sprawdzić dokładność oprogramowania Photoplan, niezależnie dokonano częściowego obrysu tachimetrem (il. 10). Po obróbce zdjęć linie obu pomiarów nałożyły się idealnie. W przypadku wybranych elementów zakładano dodatkowy, niezależny fotoplan. W taki sposób obrysowano m.in. bordiurę sgraffitowa elewacji wschodniej kamienicy $\mathrm{C}$, wpasowując ja później do widoku elewacji. Za pomocą wyskalowanych zdjęć obrysowano także m.in. lwa przy kręconych schodach. Przede wszystkim fotoplan zastosowano do rysunków elewacji oraz rozwinięcia dwóch widoków ścian wzdłużnych kamienicy A. Stopień dokładności przerysu jest już indywidualną sprawą wykonawcy dokumentacji. Dla przykładu w kamienicy A, dla której całościowo rozrysowano widok w skali 1-50 z warstwami, wykonano również fragment elewacji w skali 1-20 ze zróżnicowaniem każdej cegły (il. 11).

W tym miejscu należy jeszcze powiedzieć kilka zdań na temat przydatności tachimetru przy obrysie detalu. Metodę ta postanowiono opracować również kręcone schody parteru budynku C. Obrys wykonano jednocześnie z rzutem i przekrojami, zachowując dokładność zbierania punktów pomiarowych do tego stopnia, aby możliwe było późniejsze wyciagnięcie rysunków w większej dokładności (il. 8). Z jednego obrysu uzyskano zatem schody w rzutach i przekrojach 1-50 oraz osobny dokładny w skali $1-20^{29}$.

\footnotetext{
26 Wykorzystywano standardową lustrzankę Canon 600D z obiektywem EFS 17-85.

27 Po wklejeniu zdjęcia zob. zakładka: PhoToPlan - Rectification of photos - New Add/Redefine - Rectify.

28 Zakładka: PhoToPlan - Merge - Add - Merge.

29 Dokładność pomiaru była taka sama. Różnica polegała na większej ilości pokazanych linii, np. przerywanej linii podstopnicy w skali 1-20.
} 
Z bardzo dużą dokładnością, wykorzystując już do pomiaru okular oraz linię splajn w Aut ${ }^{\circ} \mathrm{CAD}$, możliwe było także opracowanie profilowania desek balustrady. Jest to jednak proces niezmiernie czasochłonny. Na inwentaryzację schodów poświęcono trzy dni robocze.

Zdecydowanie szybciej, w dwa dni, wykonano rysunki więźb dachowych kamienic B i C - ich przekroju podłużnego, dwóch poprzecznych oraz widoku. W pierwszej kolejności należało rozwiązać problem stopnia dokładności rysunku. Zakładając skalę 1-50 z granicą błędu 2-3 cm, należało uwzględnić wszelkie odkształcenia i ugięcia elementów więźby, np. miejsce przecięcia belek wiązarowych i jętek znacznie odbiegały od miejsca ich połączenia z krokwia. Przyjęto zasadę pokazania wszelkich linii widokowych elementów ciętych oraz wychylenia samych krokwi, z jednoczesnym uproszczeniem wiązarów w widokach za miejscem cięcia w przekroju poprzecznym. Nałożenie się kilkunastu linii unieczytelniłoby tylko rysunek. Na podstawie zebranego pomiaru wiadomo, że przesunięcie jętki od miejsca zaczopowania w krokwi do przecięcia na środku wynosi do $30 \mathrm{~cm}$, a odchył szczytu elewacji frontowej kamienicy $\mathrm{C}$ ma ponad $40 \mathrm{~cm}$.

Dokładność pomiaru jaką otrzymujemy z pracy tachimetrem niespodziewanie przynosi również pewne problemy, zwłaszcza w tego typu zabytkach, gdzie mamy bardzo duże krzywizny ścian. Przyjmując miejsce cięcia dla przekrojów, nie można ich już znacznie zmieniać na różnych kondygnacjach, aby np. pokazać otwór drzwiowy lub okienny. W momencie zmiany miejsca cięcia pomiędzy piętrami przekrój ściany rozszerza się nieproporcjonalnie. Dlatego niestety nie zawsze udało się poprowadzić rysunek zgodnie z zasadami inwentaryzacji.

\section{Podsumowanie}

W podsumowaniu należałoby jeszcze choć pokrótce porównać przydatność przyjętej tu metody w stosunku do pomiaru ręcznego oraz skaningu laserowego. Praca tachimetrem wraz z oprogramowaniem TachyCAD-PhoToPlan znacznie przyspiesza wykonanie dokumentacji pomiarowo-rysunkowej, zachowując jej bardzo dużą dokładność. Praca na samym zabytku trwa może nieco dłużej, niż podczas zbierania pomiaru ręcznego, natomiast 
od razu powstaja prawie skończone rysunki rzutów, przekrojów i widoków $^{30}$. W przeciwieństwie do skanera laserowego, nie tworzono tu chmury punktów. Laser prowadzono jedynie w określonych miejscach przekrojów. Do widoków stosowano obrys prostowanych zdjęć. Jak ma wyglądać dokumentacja, trzeba zatem wiedzieć przed przystąpieniem do pracy. Pozwala to na przemyślane zaprogramowanie całego procesu. Wynikiem końcowym jest dokumentacja wektorowa w pliku CAD oraz wydruki PDF. Daje to możliwość późniejszego jej wykorzystania podczas prowadzonych badań architektonicznych oraz prac adaptacyjnych.

Oczywiście praca skanerem laserowym trwa nieporównywalnie szybciej $^{31}$. Wiążą się z tym jednak trzy zasadnicze problemy. Otrzymana chmura punktów nie zawsze obejmuje wszystkie elementy konstrukcyjne, np. wiązary więźb dachowych czy empory. Po drugie, nieobrobiona chmura punktów nie jest właściwie przydatna $\mathrm{w}$ dalszym procesie konserwacji i restauracji zabytków architektury. Dotyczy to również widoków prostowanych zdjęć ${ }^{32}$. Po trzecie, szybkie zebranie pomiaru (co jest oczywiście opłacalne z ekonomicznego punktu widzenia) uniemożliwia dokładną analizę inwentaryzowanego zabytku. Nawet przy dokumentacji rysunkowej jest ona bowiem niezmiernie ważna. Oczywiście skaner laserowy w rękach osób specjalizujacych się w inwentaryzacji zabytków jest narzędziem niezwykle przydatnym.

Tu pojawia się jeszcze problem wykształcenia inwentaryzatorów. $\mathrm{Na}$ stronie internetowej jednej z firm reklamujących profesjonalna dokumentację zabytków zaprezentowany jest przekrój podłużny jednego z zamków. Grubość sklepienia na piętrze sięga ponad półtora metra. Wykonawca nie przewidział, że skaner nie prześwietli podłogi, pod którą muszą leżeć jeszcze belki stropu, założonego nad sklepieniem. Osoby takie powinny mieć zatem przynajmniej podstawowa wiedzę w zakresie historii technik budowalnych.

$\mathrm{Na}$ zakończenie warto jeszcze parę słów poświęcić przydatności tej metody przy dalszych badaniach architektonicznych. Po pierwsze, wykorzystując PhoToPlan, uzyskujemy bardzo dużą dokładność widoków ścian

\footnotetext{
30 Niestety, na miejscu pomiaru potrzebny też jest dostęp do prądu.

31 Zob. przyp. 4.

32 Próbując np. wykonać rysunki rekonstrukcji wcześniejszych faz budowalnych, i tak w pierwszym rzędzie fotoplan należy obrysować w systemie CAD.
} 
(co do warstwy lub wątku cegieł). Oszczędza to czas podczas analizy węzłów badawczych. Dokładność pomiaru tachimetrem pozwala na obserwację pewnych anomalii mających, jak się później okaże, uzasadnienie podczas analizy przekształceń budowalnych. Np. w kamienicy C podczas pomiaru okazało się, że ściana międzytraktowa parteru jest nieproporcjonalnie szeroka - najprawdopodobniej była to wcześniej główna ściana szczytowa; w piwnicy zaś podciag w pierwszym i drugim trakcie nie są na jednej linii, co świadczy o niezależnych przebudowach obu części. Możliwość pracy we wszystkich trzech kamienicach na jednym wspólnym rysunku daje również możliwość uchwycenia rzeczywistej grubości ścian piwnic ${ }^{33}$.

Podsumowując, inwentaryzacja pomiarowo-rysunkowa przy wykorzystaniu tachimetru z oprogramowaniem TachyCAD-PhoToPlan nie jest może metodą najszybszą, ale daje bardzo dużą dokładność. Zmusza jednocześnie wykonawców do szczegółowej analizy struktury budowanej zabytku. Docelowo przekłada się to na jakość merytoryczną wykonanej dokumentacji i jej przydatności w dalszych badaniach i pracach konserwatorsko-restauratorskich.

Bardzo duży wachlarz metod inwentaryzacyjnych, jakie oferowane sa dziś na rynku przez wiele firm skłania do konkluzji, aby w przyszłości zastanowić się nad wprowadzeniem określonych standardów inwentaryzacji. Powinny one dokładnie określać metodę pomiaru oraz dokładność samej dokumentacji, co związane jest z celem, jakiemu ma ona służyć.

\section{Summary}

\section{The use of photogrammetry and tacheometry in documentation of architectural monuments on the example of measured and drawn catalouging of certain tenement houses in Torun}

The use of photogrammetry and tacheometry in documentation of architectural monuments on the example of measured and drawn catalouging of certain tenement houses in Torun. The aim ot the text is to present the method of

33 Więcej na temat przydatności nowoczesnych metod inwentaryzacji w badaniach architektonicznych zob. A. Druzynski v. Boetticher, Mo:̀liwości wspótczesnych metod inwentaryzacii pomiarowo-rysunkowej $i$ ich znaczenie dla badań architektonicznych, [w:] Badania architektoniczne. Historia i perspektyny rozwoju, red. M. Arszyński, M. Prarat, U. Schaaf, B. Zimnowoda-Krajewska, Toruń 2015, s. (w druku). 
measuring architectural monuments by using tacheometry and photogrammetry, and to determine its suitability for further research and conservation work. In 2014, in the course of the project run at the Fine Arts Faculty, the abovementioned method was used to prepare the documentation of three tenement houses at 6 Mostowa St. im Toruń.

Tacheometry, photogrammetry, measured and drawn catalouging, architectural research, Toruń tenement house.

Wyniki badań prezentowane w publikacji uzyskane zostały w ramach projektu pod nazwą WIELOMODUŁOWE INTERDYSCYPLINARNE BADANIA NIENISZCZACEE OBIEKTÓW ARCHITEKTURY NA PRZYKŁADZIE GOTYCKICH KAMIENIC MIESZCZAŃSKICH W TORUNIU współfinansowanego ze środków Europejskiego Funduszu Rozwoju Regionalnego w ramach Regionalnego Programu Operacyjnego Województwa Kujawsko-Pomorskiego na lata 2007-2013 oraz ze środków Budżetu Państwa

Research results which were presented in the paper were attained during the WIELOMODULOWE INTERDYSCYPLINARNE BADANIA NIENISZCZACE OBIEKTÓW ARCHITEKTURY NA PRZYKLADZIE GOTYCKICH KAMIENIC MIESZCZAŃSKICH W TORUNIU project. The project was co-funded by European Regional Development Fund within the framework of Regional Operational Programme for Kujawsko-Pomorskie Voivodeship for the years 2007-2013 and by the Government Budget. 


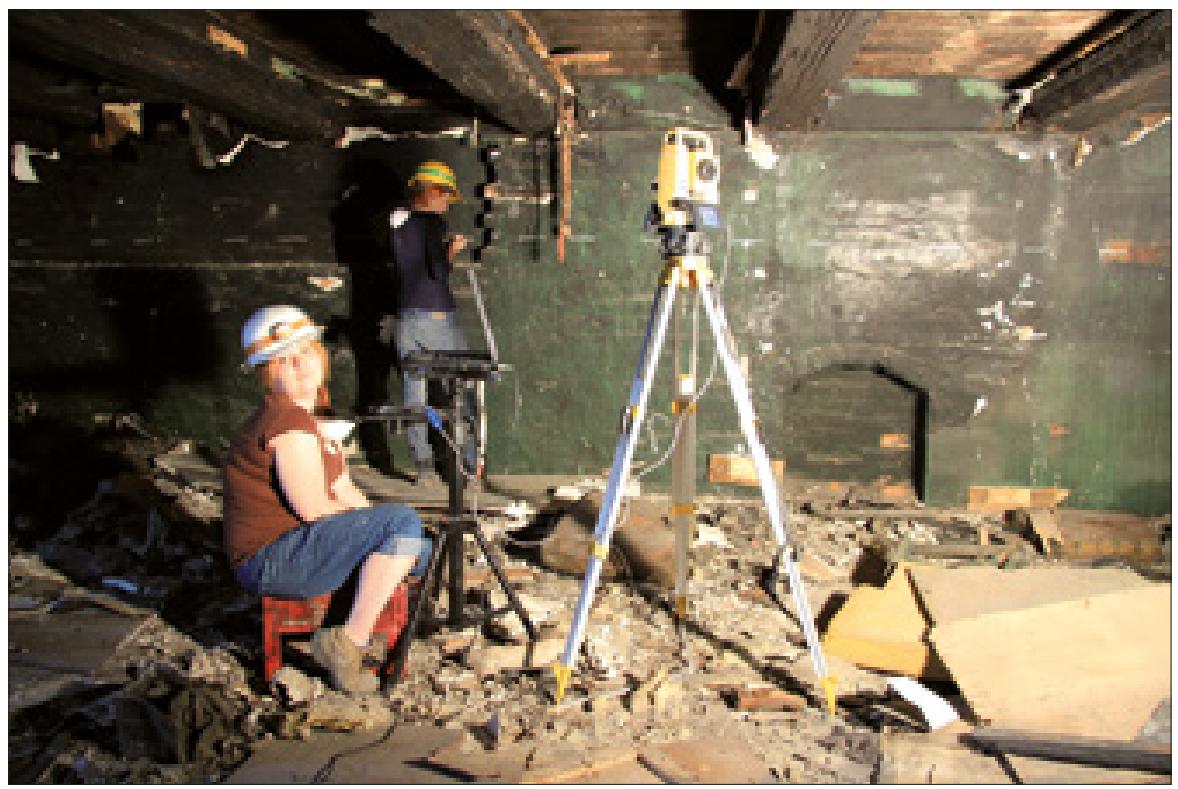

1. Zespół kamienic na ul. Mostowej 6. Inwentaryzacja pomiarowo-rysunkowa z wykorzystaniem tachimetra. Zakładanie punktów kontrolnych (fot. M. Prarat, 2014 r.)

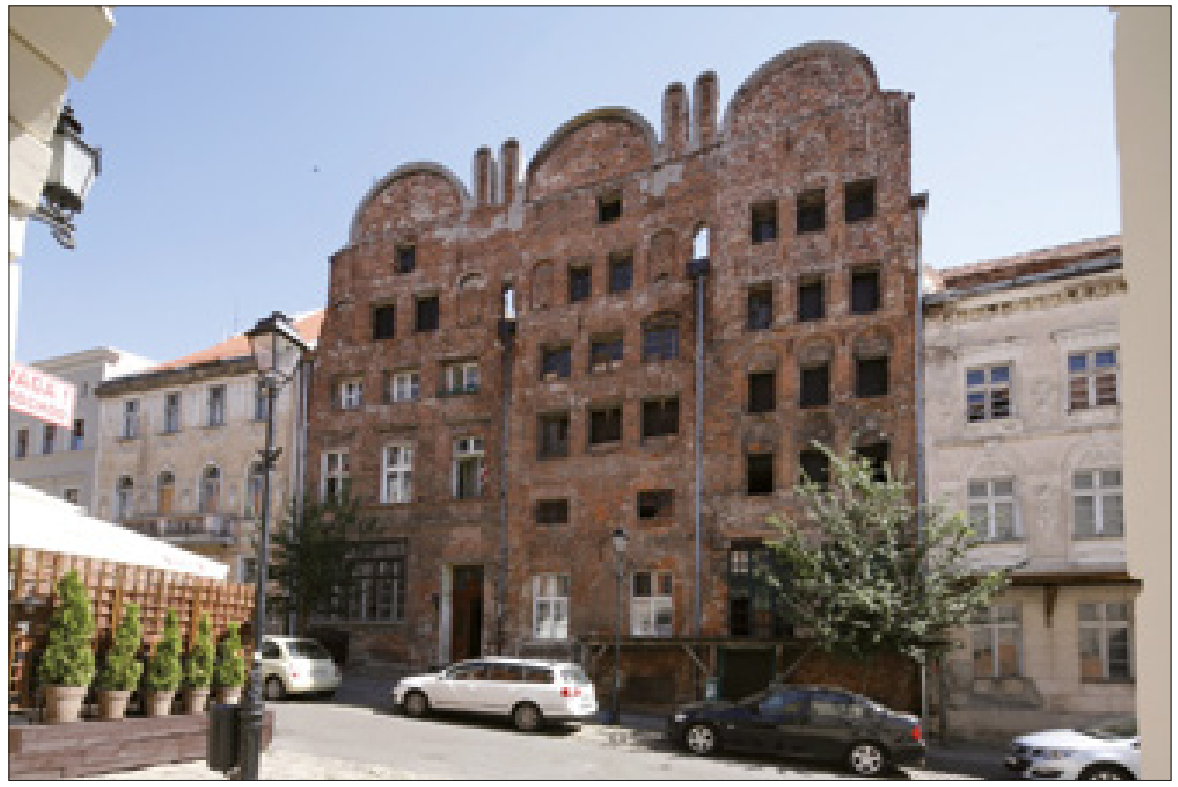

2. Zespół kamienic na ul. Mostowej 6 (fot. M. Kumorowicz, 2014 r.) 


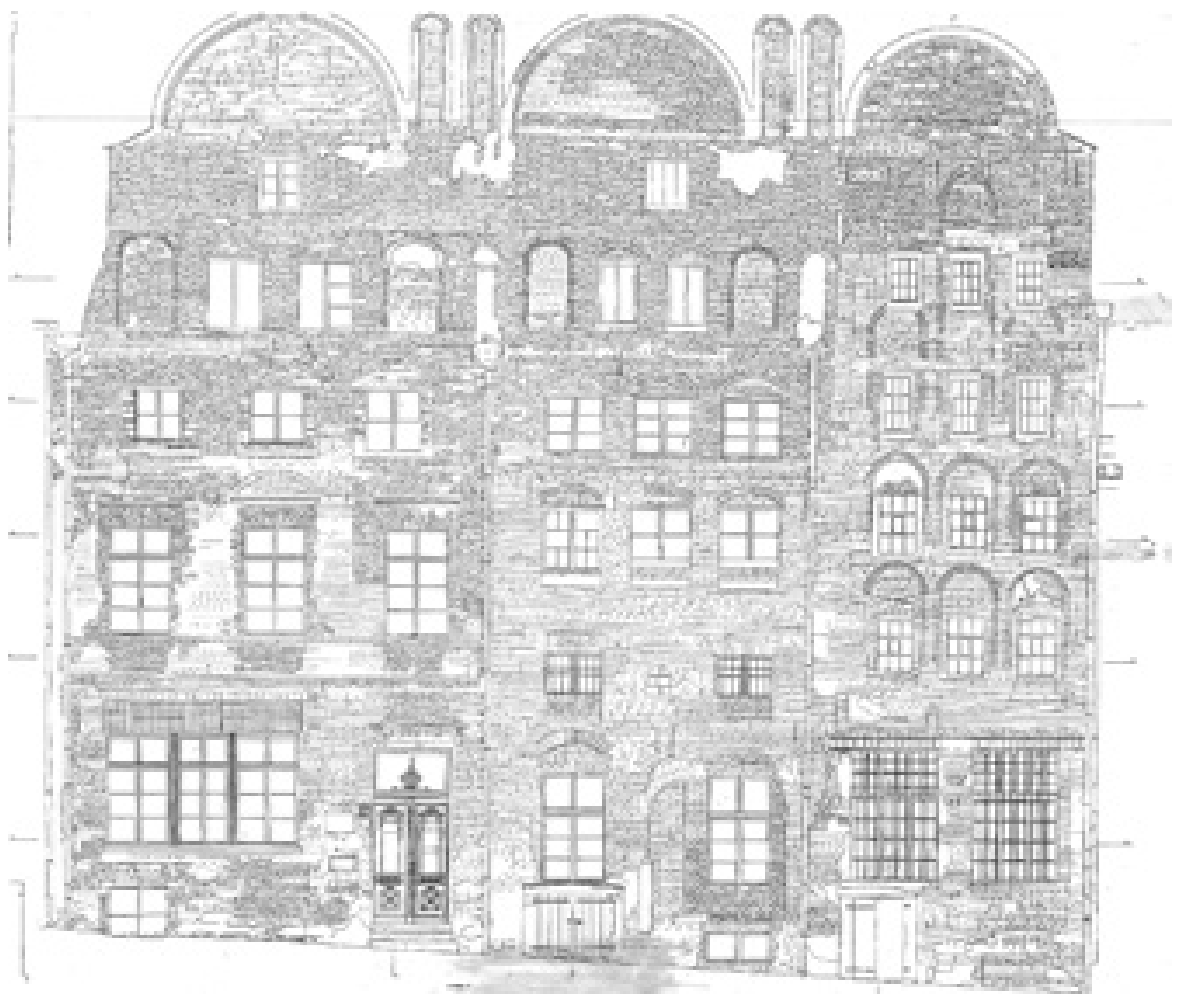

3. Zespół kamienic na ul. Mostowej 6. Inwentaryzacja elewacji za pomocą fotogrametrii wykonana w latach 80. XX w. (archiwum Miejskiego Konserwatora Zabytków w Toruniu) 


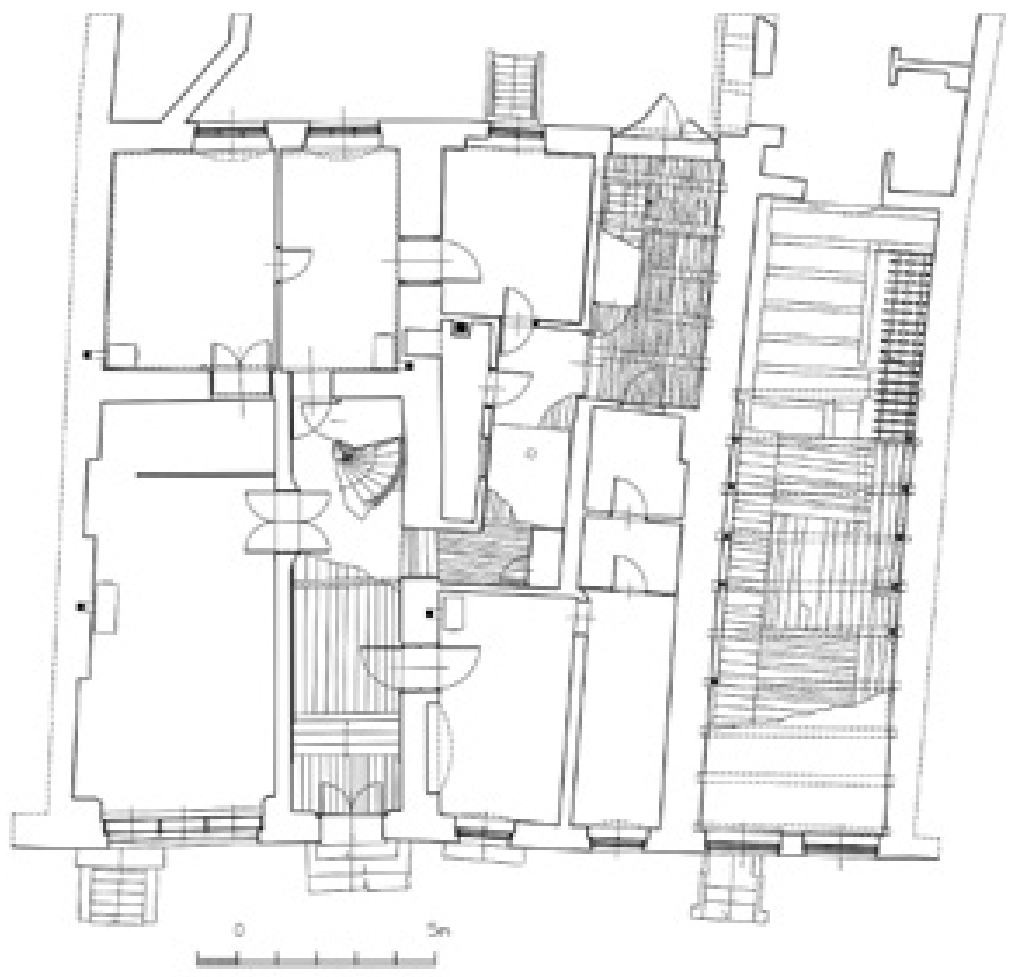

4. Zespół kamienic na ul. Mostowej 6. rysunek rzutu przyziemia wszystkich budynków (oprac. M. Prarat, M. Grabowska, M. Kumorowicz) 


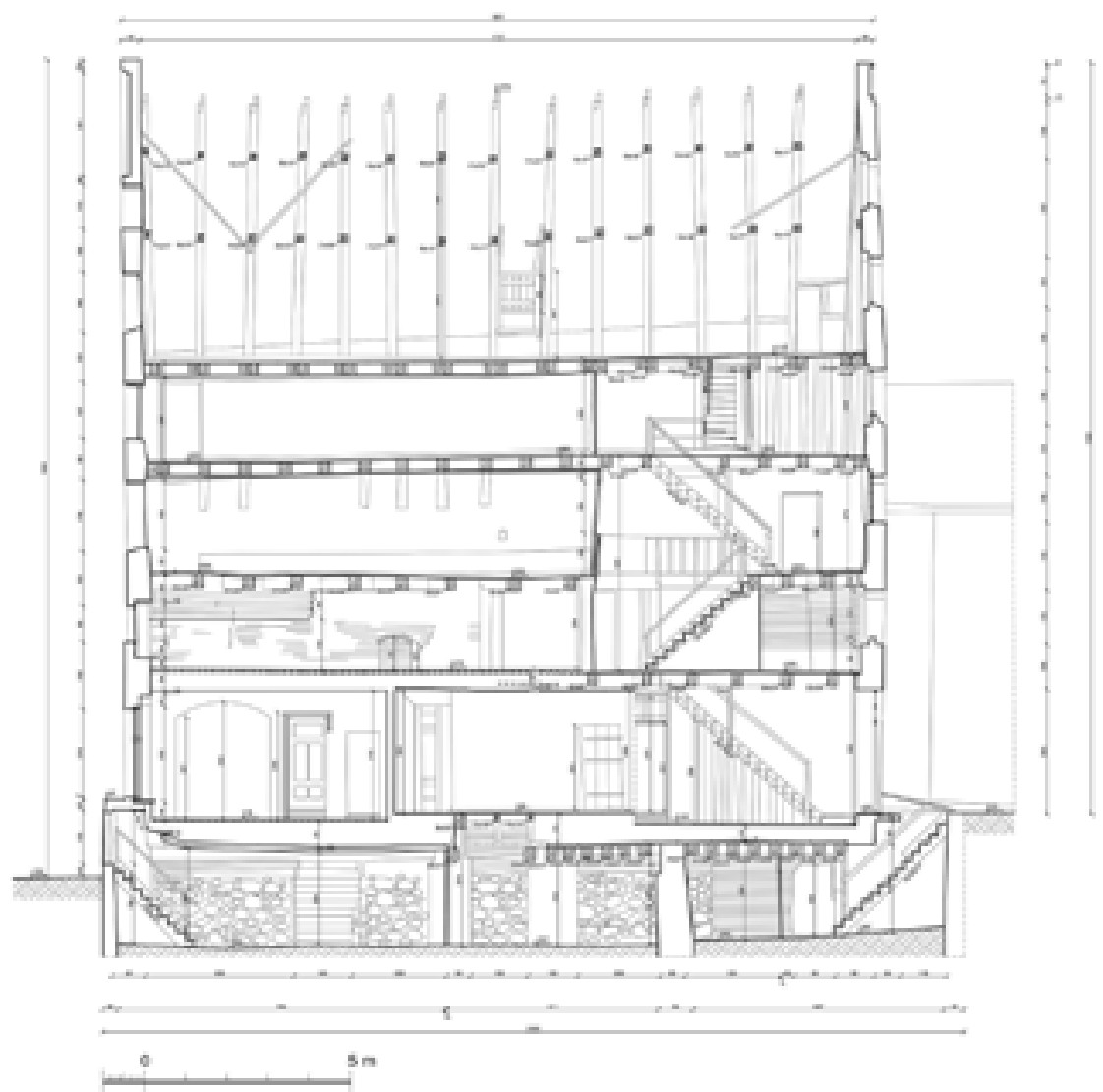

5. Zespół kamienic na ul. Mostowej 6. Inwentaryzacja pomiarowo-rysunkowa wykonana za pomocą tachimetrii i fotogrametrii. Przekrój podłużny kamienicy środkowej (oprac. M. Prarat, M. Grabowska, M. Kumorowicz) 


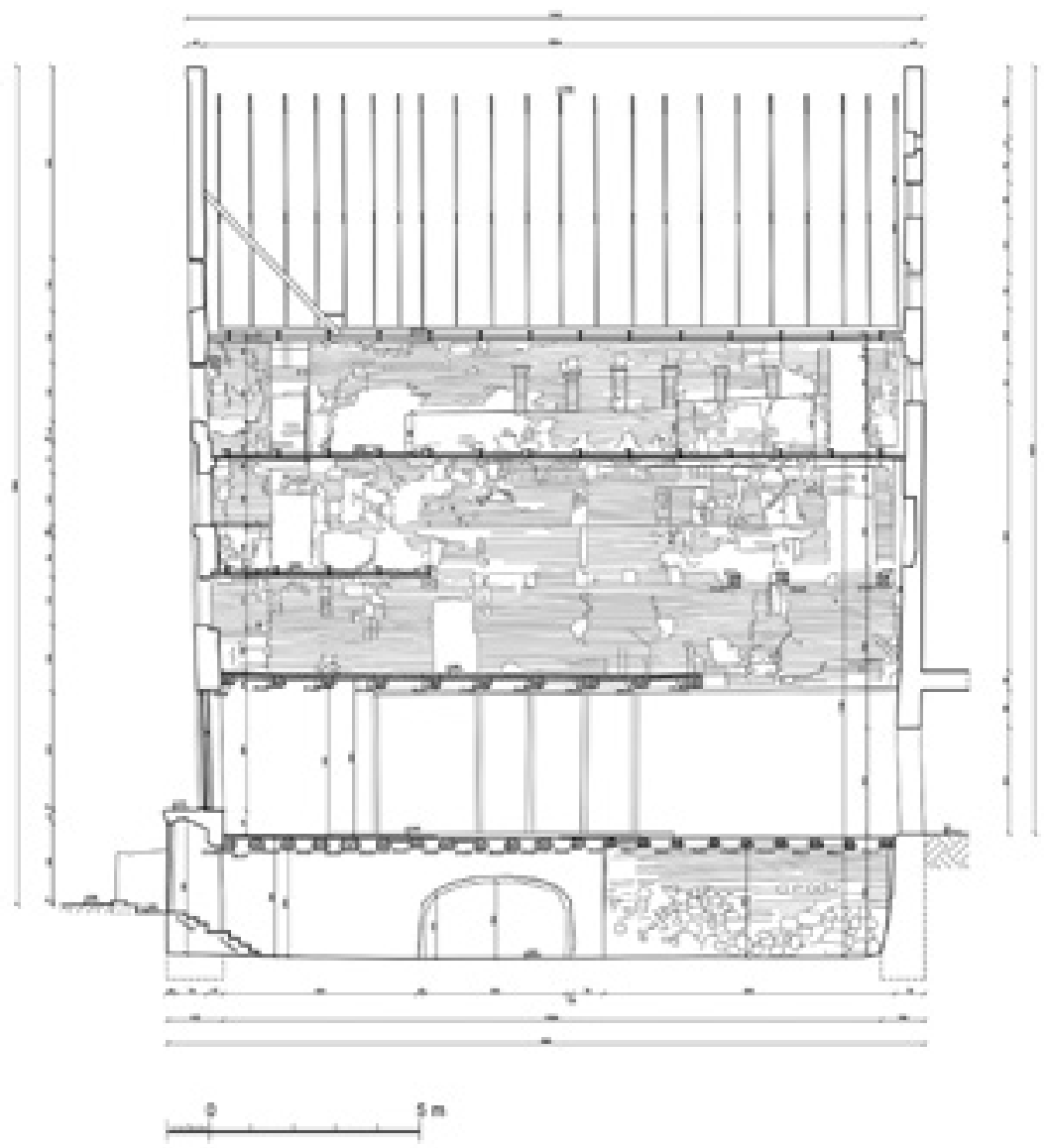

6. Zespół kamienic na ul. Mostowej 6. Inwentaryzacja pomiarowo-rysunkowa wykonana za pomoca tachimetrii i fotogrametrii. Przekrój podłużny kamienicy południowej z widokiem na ścianę północną (oprac. M. Prarat, M. Grabowska, M. Kumorowicz) 


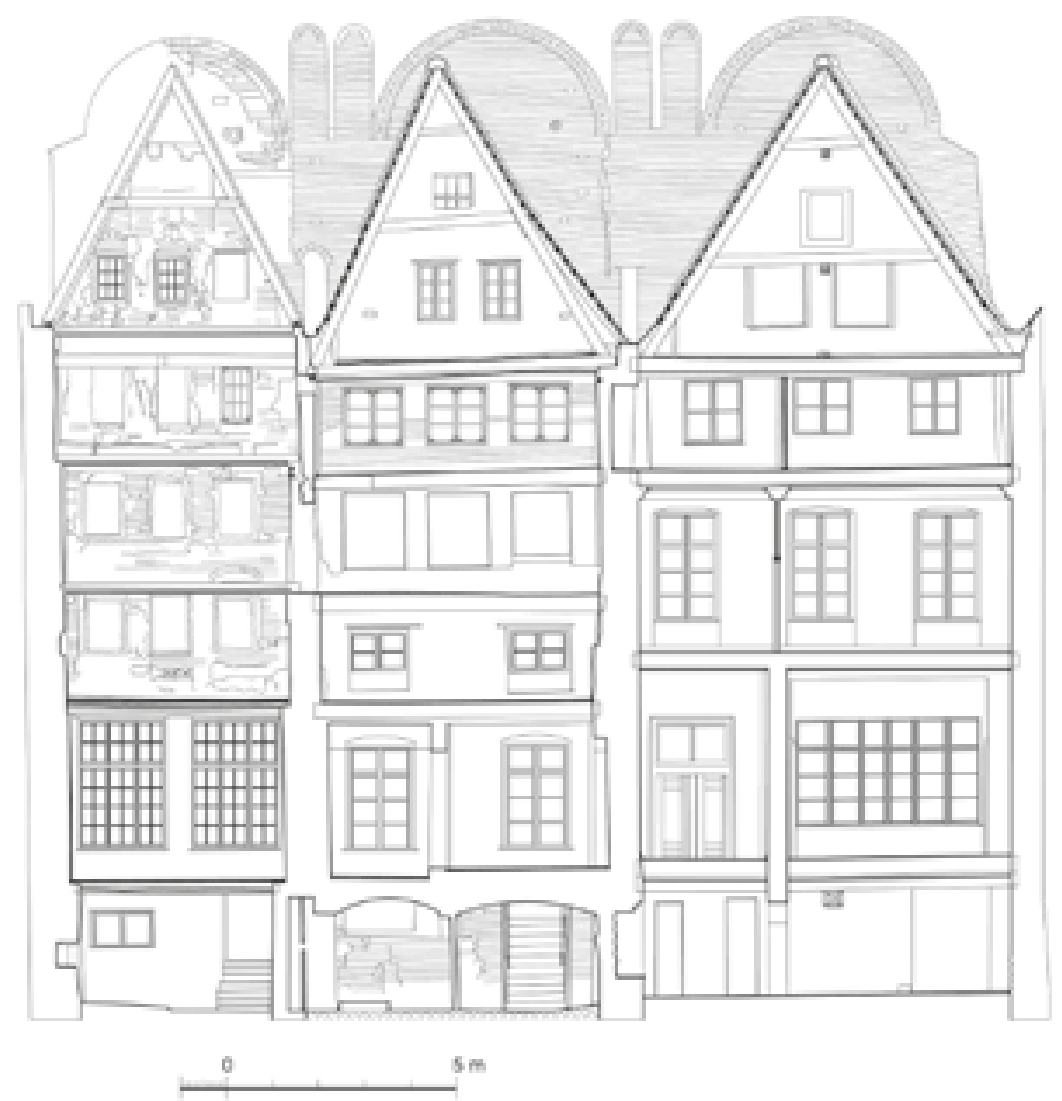

7. Zespół kamienic na ul. Mostowej 6. Inwentaryzacja pomiarowo-rysunkowa wykonana za pomocą tachimetrii i fotogrametrii. Przekrój poprzeczny z widokiem na ścianę zachodnią (oprac. M. Prarat, M. Grabowska, M. Kumorowicz) 

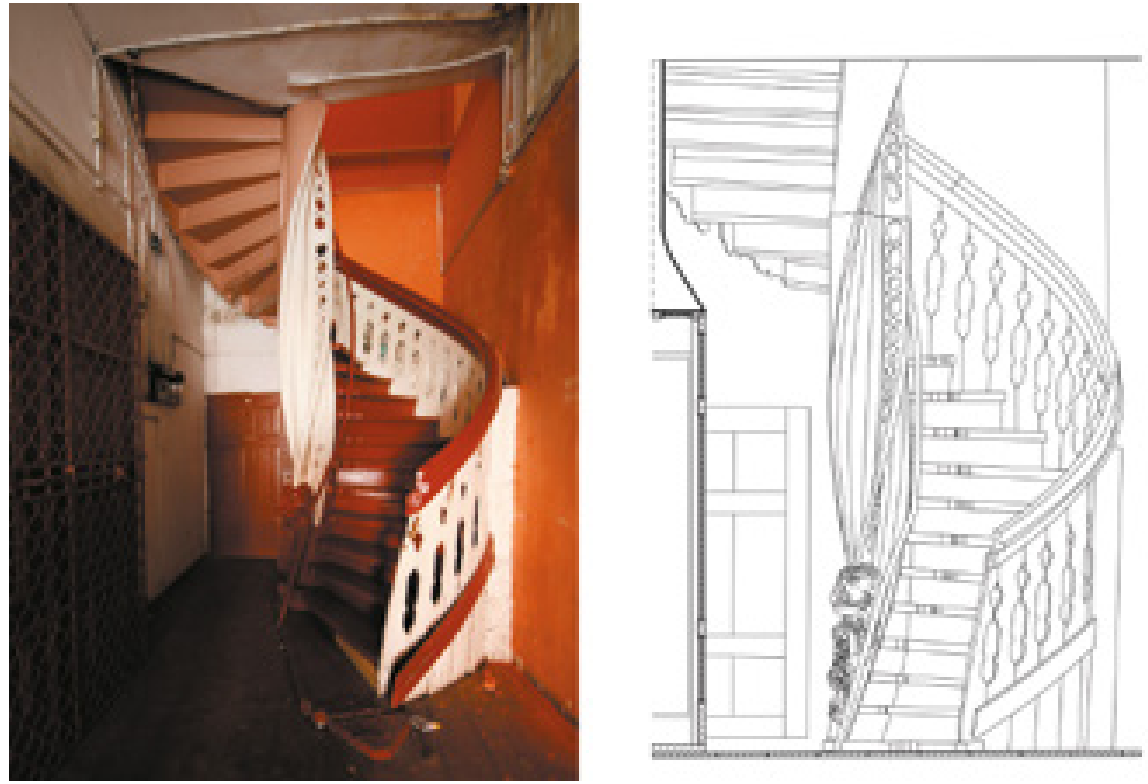

8. Zespół kamienic na ul. Mostowej 6. Inwentaryzacja pomiarowo-rysunkowa kręconych schodów kamienicy północnej wykonana za pomocą tachimetrii i fotogrametrii (oprac. M. Prarat, M. Grabowska, M. Kumorowicz) 


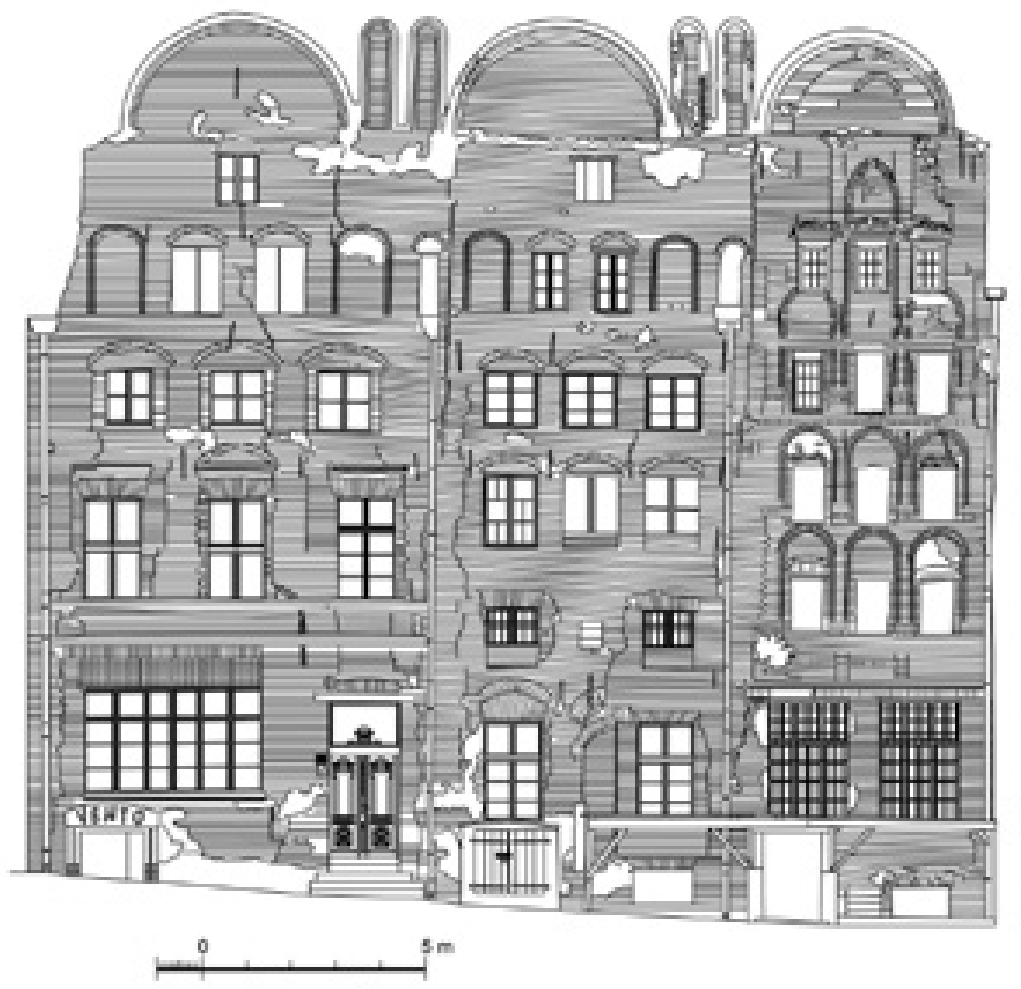

9. Zespół kamienic na ul. Mostowej 6. Inwentaryzacja pomiarowo-rysunkowa elewacji z za pomoca tachimetrii i fotogrametrii w skali 1-50 (oprac. M. Prarat, M. Grabowska, M. Kumorowicz) 


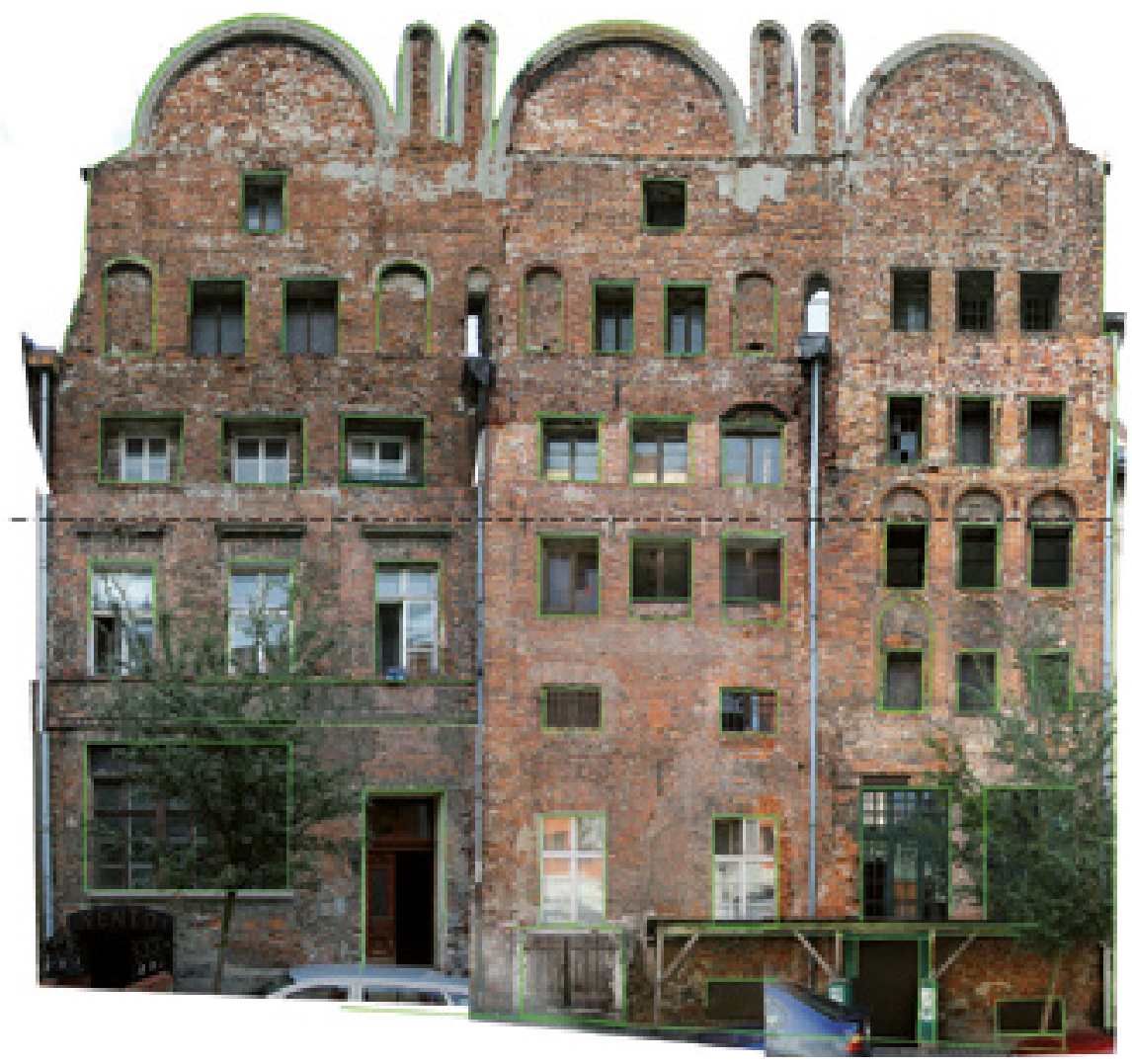

10. Zespół kamienic na ul. Mostowej 6. Widok wyskalowanych zdjęć elewacji. Kolorem zielonym zaznaczony niezależny pomiar wykonany tachimetrem. (oprac. M. Prarat, M. Grabowska, M. Kumorowicz) 


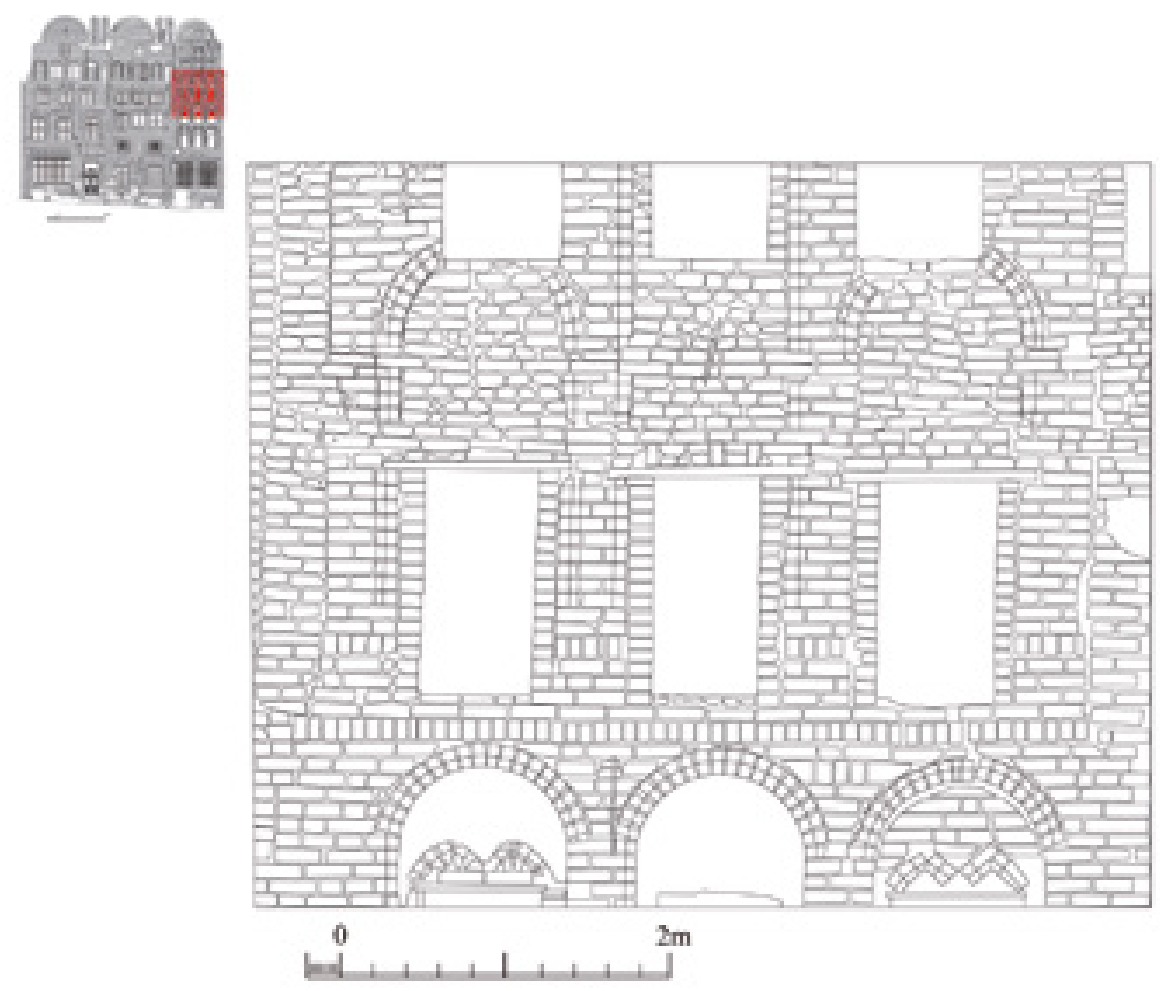

11. Zespół kamienic na ul. Mostowej 6. Inwentaryzacja pomiarowo-rysunkowa fragmentu elewacji kamienicy południowej za pomoca tachimetrii i fotogrametrii w skali 1-20. (oprac. M. Prarat) 
